\title{
DAYA PREDASI IKAN CUPANG (Betta splendens) DAN IKAN GUPPY (Poecilia reticulate) TERHADAP LARVA INSTAR III NYAMUK Aedes aegypti SEBAGAI UPAYA PENGENDALIAN VEKTOR PENYAKIT DEMAM BERDARAH DENGUE (DBD)
}

\author{
Siti Mutmainah, Eko Prasetyo, Lilis Sugiarti* \\ *Program Studi DIII Farmasi STIKES Cendekia Utama Kudus \\ Jl. Lingkar Raya Kudus-Pati KM. 5 Jepang Kecamatan Mejobo Kabupaten Kudus \\ *e-mail : lilis_suwarno@yahoo.co.id
}

\section{ABSTRACT \\ Beta Fish Predation Power and Guppies Against the Third Instar Larvae of Mosquitos as a Vector Control Efforts in Dengue Fever}

\begin{abstract}
Dengue Hemorrhagic Fever (DHF) disease was a disease caused by dengue virus infection remains a public health problem in Indonesia. The disease attacks all age groups every years. Effort to eradication DHF done by fulfill the predator of fish like cupang and guppy. The study to determined the difference of predation potential between betta and guppy toward the $3^{\text {rd }}$ instar of larvae Aedes aegypti. This study was experimental with comparative study and one shoot chase study design. The population was larvae of Aedes aegypti mosquito 3rd instar with betta and guppy as many as 5. Every treatment used the larvae as many as 25. The treatment observe in 1, 2, 4 and 6 hours the data analyze used the independent samples test. The results of independent samples test got the $p$ value 0.000 , proves there were the significantly difference of predation potential of betta and guppy toward the $3^{\text {rd }}$ instar III of Larvae Aedes aegypti mosquito. Suggested to the society can used the predator fish to eradication the DHF disease.
\end{abstract}

Keywords: The potential of predator fish Cupang (Betta sp.), Guppy (Poecilia reticulata), $3^{\text {rd }}$ instar of larvae, Aedes aegypti.

\begin{abstract}
ABSTRAK
Demam Berdarah Dengue (DBD) merupakan penyakit yang disebabkan oleh virus dan ditularkan oleh nyamuk Aedes aegypti yang masih menjadi masalah kesehatan masyarakat di Indonesia. Penyakit ini menyerang semua kelompok umur dan muncul setiap tahun. Pengendalian DBD dilakukan dengan memanfaatkan ikan seperti ikan cupang dan guppy. Penelitian ini bertujuan untuk mengetahui perbedaan daya predasi ikan cupang (Betta sp.) dan ikan guppy (Poecilia reticulata) terhadap larva instar III nyamuk Aedes aegypti. Jenis penelitian ini adalah eksperimental bersifat komparatif dengan desain one shoot chase study. Subyek penelitian adalah larva nyamuk Aedes aegypti instar III, ikan cupang dan guppy masing-masing sebanyak 5 ekor. Setiap waktu pengamatan menggunakan larva instar III sebanyak 25 ekor dan diulang sebanyak 5 kali. Pengamatan dilakukan selama 1, 2, 4 dan 6 jam. Analisis data menggunakan independent samples test. Hasil uji Independent Samples Test didapatkan nilai $\mathrm{p}$ value 0.000 , membuktikan adanya perbedaan yang bermakna antara daya predator ikan cupang (Betta sp.) dengan ikan guppy (Poecilia reticulata) terhadap larva instar III nyamuk Aedes aegypti. Daya predator paling baik adalah ikan cupang. Disarankan kepada masyarakat untuk memanfaatkan ikan predator dalam upaya mengendalikan penyakit Demam Berdarah.
\end{abstract}

Kata Kunci: daya predator ikan cupang (Betta sp.), ikan guppy (Poecilia reticulata), larva instar III nyamuk Aedes aegypti.

\section{PENDAHULUAN}

Penyakit Demam Berdarah Dengue (DBD) masih merupakan salah satu masalah kesehatan masyarakat yang utama di Indonesia. Jumlah penderita dan luas daerah penyebarannya semakin bertambah seiring dengan meningkatnya mobilitas dan kepadatan penduduk. Demam berdarah adalah penyakit demam akut yang disebabkan oleh virus dengue, yang masuk ke peredaran darah manusia melalui gigitan nyamuk dari genus Aedes, misalnya Aedes aegypti atau Aedes albopictus. Aedes aegypti 
adalah vektor yang paling banyak ditemukan menyebabkan penyakit ini. Nyamuk dapat membawa virus dengue setelah menghisap darah orang yang telah terinfeksi virus tersebut. Sesudah masa inkubasi virus di dalam nyamuk selama 8-10 hari, nyamuk yang terinfeksi dapat mentransmisikan virus dengue tersebut ke manusia sehat yang digigitnya (Depkes, 2011).

Di Indonesia demam berdarah pertama kali ditemukan di kota Surabaya pada tahun 1968, dimana sebanyak 58 orang terinfeksi dan 24 orang diantaranya meninggal dunia (Angka Kematian : 41,3 $\%)$. Sejak saat itu, penyakit ini menyebar luas ke seluruh Indonesia (Pusat Data dan Surveilans Epidemiologi Kemenkes RI, 2010). Menurut Riskesdas (2014) pada tahun 2013, jumlah penderita DBD yang dilaporkan sebanyak 112.511 kasus dengan jumlah kematian 871 orang (Incidence Rate/Angka kesakitan $=45,85$ per 100.000 penduduk dan CFR/angka kematian= $0,77 \%)$. Terjadi peningkatan jumlah kasus pada tahun 2013 dibandingkan tahun 2012 yang sebesar 90.245 kasus dengan IR 37,27. Pada tahun 2014, sampai pertengahan bulan Desember tercatat penderita DBD di 34 provinsi di Indonesia sebesar 71.668 orang, 641 diantaranya meninggal dunia. Angka tersebut lebih rendah dibandingkan tahun sebelumnya (2013) dengan jumlah penderita sebanyak 112.511 orang dan jumlah kasus meninggal sebanyak 871 (Depkes, 2015).

Menurut Depkes (2010) penyakit DBD dapat muncul sepanjang tahun dan dapat menyerang seluruh kelompok umur. Penyakit ini berkaitan dengan kondisi lingkungan dan perilaku masyarakat. Dalam rangka mengurangi dampak negatif dari kondisi lingkungan, maka diperlukan pengendalian vektor nyamuk penyebab DBD. Peraturan Menteri Kesehatan RI Nomor 374 tahun 2010 tentang Pengendalian Vektor, menyatakan bahwa ada beberapa metode yang dapat digunakan diantaranya adalah metode pengendalian fisik dan mekanis yang merupakan upayaupaya untuk mencegah, mengurangi, menghilangkan habitat perkembangbiakan dan populasi vektor secara fisik dan mekanik. Selain metode pengendalian fisik dan mekanis, terdapat juga metode pengendalian dengan menggunakan agen biotik dan metode pengendalian secara kimia.

Pengendalian penularan penyakit DBD di Indonesia terutama dilakukan dengan menggunakan insektisida golongan organofosfat (malation dan temefos) untuk menurunkan kepadatan vektornya. Malation dan temefos selalu digunakan dalam program nasional pengendalian DBD di Indonesia sejak tahun 1970-an. Penggunaan larvasida dalam waktu yang lama dapat menimbulkan resistensi. Pengendalian secara biologis merupakan upaya pemanfaatan agen biologi untuk pengendalian vektor DBD. Beberapa agen biologis yang sudah digunakan dan terbukti mampu mengendalikan populasi larva vektor DB/DBD adalah dari kelompok bakteri, predator seperti ikan pemakan jentik dan cyclop (Copepoda). Predator larva di alam cukup banyak, namun yang bisa digunakan untuk pengendalian larva vektor DBD tidak banyak jenisnya dan yang paling mudah didapat dan dikembangkan masyarakat serta murah adalah ikan pemakan jentik (Depkes, 2011).

Menurut penelitian Utama (2010) upaya pengendalian demam berdarah secara biologi salah satunya dengan memelihara ikan. Pemanfaatan ikan dalam upaya pengendalian demam berdarah efektif dilakukan pada stadium larva, terutama larva instar III karena pada stadium ini larva mudah diidentifikasi dengan ciri adanya rambut pada seluruh tubuh, kepala tampak menghitam, tingkat metabolisme yang belum matur serta pergerakan yang lebih banyak.

Pemanfaatan ikan sebagai predator alami larva nyamuk adalah salah satu cara pengendalian secara biologi yang mudah untuk dilakukan oleh masyarakat. Metode pengendalaian secara biologis ini dapat mengurangi kepadatan larva nyamuk serta tidak menimbulkan masalah bagi kesehatan lingkungan (Depkes, 2010). Berdasarkan beberapa hasil penelitian yang telah dilakukan, ikan menunjukkan kemampuan yang berbeda dalam mengendalikan larva nyamuk. Penelitian Taviv dkk (2007) menunjukkan bahwa ikan cupang (Betta sp.) yang efektif untuk pengendalian larva Aedes 
aegypti adalah ikan dengan ukuran $4 \mathrm{~cm}$ atau $5 \mathrm{~cm}$. Ikan cupang tidak mati walaupun di kontainer terdapat atau ditaburi abate. Penelitian Taviv (2011) selanjutnya membuktikan bahwa pemanfaatan ikan cupang (Betta sp.) plus pemantau jentik lebih efektif meningkatkan Angka Bebas Jentik (ABJ) dan menurunkan House Index $(\mathrm{HI})$, Container Index (CI), Breteau Index (BI) dibandingkan hanya dengan pemantau jentik.

Perkasa (2010) menyatakan bahwa ikan cupang (Betta sp.) merupakan ikan yang cukup dikenal dan mudah diperoleh masyarakat karena selama ini ikan tersebut digunakan sebagai ikan hias dan ikan untuk permainan (diadu). Selain itu jenis ikan predator adalah ikan guppy (Poecilia reticulata). Penelitian Samsudrajat (2008) membuktikan bahwa pengendalian secara biologi dapat menggunakan ikan pemakan jentik (ikan adu atau ikan cupang), bakteri (Bt.H-14) dan ikan Poesilia reticulata (ikan guppy) dengan memakan larva. Ikan Poesilia reticulata (ikan guppy) dengan ukuran kira-kira $2 \mathrm{~cm}$ dalam waktu 1 hari dapat memangsa larva atau jentik nyamuk mencapai 116 ekor. Pada kontainer dengan diameter $30 \mathrm{~cm}$, ikan tersebut dapat memakan larva Aedes aegypti sebanyak 25 ekor per hari.

Penelitian Sari (2005) membuktikan bahwa rata-rata larva nyamuk Aedes aegypti yang dimakan ikan Poecilia reticulata selama 24 jam pada kelompok jantan ukuran $<2 \mathrm{~cm}$ sebanyak 14,30 ekor, untuk jantan yang berukuran $\geq 2 \mathrm{~cm}$ sebanyak 51,29 ekor untuk jantan yang berukuran $<3,5 \mathrm{~cm}$ sebanyak 90,41 ekor, dan untuk betina yang berukuran $\geq 3,5 \mathrm{~cm}$ sebanyak 101,47 ekor. Penelitian tersebut menjelaskan bahwa ada indikasi semakin panjang ukuran tubuh ikan Poecilia reticulata maka akan semakin banyak kemampuannya memakan larva nyamuk Aedes aegypti. Rata-rata kemampuan ikan Poecilia reticulata yang berjenis kelamin jantan lebih banyak dibandingkan ikan betina dalam memakan larva nyamuk Ae.aegypti. Ikan Poecilia reticulata dengan panjang tubuh $<2 \mathrm{~cm}$ dan $\geq 2 \mathrm{~cm}$ mempunyai perbedaan yang signifikan dengan panjang tubuh $<2 \mathrm{~cm}$ dengan $<3,5$ $\mathrm{cm} ;<2 \mathrm{~cm}$ dengan $>=3,5 \mathrm{~cm} ; \geq 2 \mathrm{~cm}$ dengan $<3,5 \mathrm{~cm}$ dan $\geq 2 \mathrm{~cm}$ dengan $\geq 3,5$ $\mathrm{cm}$ dalam kemampuannya memakan larva nyamuk Aedes aegypti, sedangkan yang panjang tubuhnya $<3,5 \mathrm{~cm}$ dan $\geq 3,5 \mathrm{~cm}$ tidak mempunyai perbedaan yang signifikan satu dengan yang lainnya. Sedangkan penelitian untuk mengidentifikasi perbedaan daya makan ikan cupang dan ikan guppy belum pernah dilakukan. Berdasarkan alasan tersebut penulis termotivasi untuk mengetahui perbedaan tingkat predasi ikan cupang (Betta sp.) dan ikan guppy (Poecilia reticulata) terhadap larva instar III nyamuk Aedes aegypti.

\section{BAHAN DAN METODE}

Penelitian ini dilakukan di Desa Tumpang Krasak Kecamatan Jati Kabupaten Kudus pada bulan 2 Juni 2015 jam 06.0012.00 WIB. Penelitian yang dilakukan adalah bertujuan mengetahui perbedaan tingkat predasi ikan cupang (Betta sp.) dan ikan guppy (Poecilia reticulata) terhadap larva instar III nyamuk Aedes aegypti sehingga penelitian ini termasuk jenis penelitian fenomenologi bersifat komparatif. Menurut Sastroasmoro \& Ismale (2011) penelitian komparatif adalah jenis penelitian untuk mengetahui perbedaan dari fenomena tertentu.

Jenis penelitian ini adalah Eksperimen, yaitu penelitian yang memberkan perlakuan (eksperimen) Rancangan penelitian ini menggunakan desain One shoot case study (studi kasus satu tembakan) digunakan untuk mengetahui nilai ilmiah dalam suatu pengukuran dalam penelitian eksperimen. Dimana dalam desain ini, ada satu kelompok yang diberi umpan perlakuan yang kemudian hasil dari perlakuan tersebut diobservasi, Perlakuan dalam hal ini merupakan variabel bebas dan hasilnya adalah variabel terikat.

Populasi penelitian ini adalah larva nyamuk Aedes aegypti instar III yang didapatkan dari telur yang berasal dari Balai Besar Penelitian dan Pengembangan Vektor dan Reservoir Penyakit (B2P2VRP) Salatiga.

Penelitian ini menggunakan teknik random sampling, yaitu memilih acak jenis 
larva nyamuk Aedes aegypti. Berdasarkan penelitian Taviv (2011) dan Sari (2005) besar sampel dalam penelitian ini adalah;

\section{Ikan Predator}

a. Ikan cupang sebanyak 5 ekor dengan kriteria panjang tubuh 3-4 cm, umur 2 bulan, berat 100-150 gram dan dipuasakan 1 hari.

b. Ikan guppy sebanyak 5 ekor dengan kriteria panjang tubuh 3-4 cm, umur 2 bulan, berat 100-150 gram dan dipuasakan 1 hari.

2. Larva instar III

Larva instar III setiap perlakuan berjumlah sebanyak 100 ekor dengan pengamatan diulang 5 kali sehingga jumlah total sebanyak $100 \times 5 \times 2=1.000$ ekor larva instar III. Pengulangan ini berdasarkan dari penelitian sebelumnya yaitu penelitian Taviv (2011).

Notoatmodjo (2010) menyatakan instrumen penelitian adalah alat yang digunakan dalam pengumpulan data agar pekerjaannya lebih mudah dan hasilnya lebih baik. Instrument dalam penelitian ini adalah;

1. Alat Penelitian
a. Air dalam wadah toples plastik.
b. Alat tulis
c. Alat penghitung (counter)
d. Sendok
e. Kamera

2. Bahan Penelitian
a. Larva instar III Aedes aegypti
b. Ikan cupang
c. Ikan guppy

\section{Metode Pengumpulan Data}

1. Tahap Persiapan

a. Wadah toples plastik untuk menampung air yang nantinya digunakan untuk menempatkan obyek penelitian.

b. Telur larva instar III nyamuk Aedes aegypti sebanyak 1.000 ekor.

2. Penyediaan Larva Aedes aegypti

a. Telur nyamuk Aedes aegypti didapatkan dari Balai Besar Penelitian dan Pengembangan Vektor dan Reservoir Penyakit (B2P2VRP) Salatiga. b. Telur nyamuk dipelihara sampai menetas menjadi larva instar I, kemudian berkembang menjadi instar II dan III.

c. Larva instar III kemudian dikelompokkan sesuai kebutuhan, yaitu jumlah masing-masing perlakuan 100 ekor dengan pengamatan 5 kali.

3. Langkah Pengumpulan Data

Langkah pengumpulan data dalam penelitian ini adalah;

a. Disiapkan 10 toples plastik, masingmasing diisi air dengan volume 1000 $\mathrm{ml}$.

b. Dari 10 toples diisi 100 larva instar III tanpa diberi makan, 5 toples diisi ikan gupi dan 5 toples ikan cupang.

c. Pengamatan dilakukan pada 1 jam, 2 jam, 4 jam dan 6 jam, kemudian dihitung jumlah larva yang dimakan ikan predator.

\section{Analisis Data}

1. Uji Normalitas Data

Uji normalitas data dalam penelitian ini dilakukan dengan uji One Sample Kolmogorov Smirnov pada taraf signifikansi 5\%. Hasil uji normalitas data mendapatkan kesimpulan bahwa data terdistribusi normal sehingga termasuk data parametrik.

2. Uji Analisis Data

Berdasarkan uji normalitas data, maka uji statistik menggunakan uji beda dua mean independent dengan uji independent samples test. Rumus dari korelasi uji t untuk varian yang sama adalah :

$$
\begin{aligned}
& T=\frac{\bar{X}-\bar{X}}{\operatorname{Sp} \sqrt{(1 / n)+\left(1 / n^{2}\right)}} \\
& \mathrm{df}=\mathrm{n} 1+\mathrm{n} 2-2
\end{aligned}
$$

Keterangan :

n1 atau n2 : Jumlah sampel kelompok 1 atau 2

S1 atau S2 : Standar deviasi sample kelompok 1 dan 2 
Pengambilan keputusan dari hasil penghitungan tersebut adalah apabila $t$ hitung $\geq \mathrm{t}$ tabel atau $\mathrm{p}$ value $<0.05$ berarti ada perbedaan rata-rata (Riwidikdo, 2007).

\section{HASIL PENELITIAN}

\section{Analisa Univariat}

a. Distribusi Kematian Larva pada Ikan Guppy (Poecilia reticulata)

Tabel 1. Distribusi Jumlah Kematian Larva Aedes aegypti pada Ikan Guppy

\begin{tabular}{lccccc}
\hline \multirow{2}{*}{ Waktu } & \multicolumn{5}{c}{ Pengamatan (Jam } \\
\cline { 2 - 6 } & $\mathbf{1}$ & $\mathbf{2}$ & $\mathbf{3}$ & $\mathbf{4}$ & $\mathbf{5}$ \\
\hline 1 Jam & 12 & 20 & 19 & 17 & 16 \\
2 Jam & 23 & 25 & 25 & 22 & 22 \\
4 Jam & 39 & 38 & 32 & 32 & 35 \\
6 Jam & 42 & 47 & 42 & 43 & 47 \\
\hline
\end{tabular}

Berdasarkan Tabel 1. diketahui bahwa daya predasi ikan guppy pada 1 jam pertama paling banyak adalah 20 ekor, pada 2 jam paling banyak 25 ekor, pada 4 jam sebanyak 39 ekor dan pada 6 jam 47 ekor.

Berdasarkan Tabel 1. diketahui bahwa rata-rata daya makan ikan guppy terhadap larva adalah 29.9 ekor dengan daya makan paling rendah adalah 12 ekor dan daya makan paling banyak adalah 47 ekor.

b. Distribusi Kematian Larva pada Ikan Cupang (Betta sp.)

Tabel 2. Distribusi Jumlah Kematian Larva Aedes aegypti pada Ikan Cupang

\begin{tabular}{cccccc}
\hline \multirow{2}{*}{ Waktu } & \multicolumn{6}{c}{ Pengamatan (Jam Ke-) } \\
\cline { 2 - 6 } & $\mathbf{1}$ & $\mathbf{2}$ & $\mathbf{3}$ & $\mathbf{4}$ & $\mathbf{5}$ \\
\hline 1 Jam & 33 & 32 & 32 & 39 & 33 \\
2 Jam & 42 & 54 & 45 & 52 & 45 \\
4 Jam & 63 & 72 & 63 & 67 & 67 \\
6 Jam & 83 & 89 & 82 & 85 & 88 \\
\hline
\end{tabular}

Berdasarkan Tabel 2 diketahui bahwa daya predasi ikan cupang pada 1 jam pertama paling banyak adalah 39 ekor, pada 2 jam paling banyak 54 ekor, pada 4 jam sebanyak 72 ekor dan pada 6 jam 89 ekor.

Berdasarkan Tabel 2 diketahui bahwa rata-rata daya makan ikan cupang terhadap larva adalah 58.30 ekor dengan daya makan paling rendah adalah 32 ekor dan daya makan paling banyak adalah 89 ekor.

Analisis Bivariat (Perbedaan Ikan Cupang (Betta sp.) dan Ikan Guppy (Poecilia reticulata) sebagai predator Larva Instar III Nyamuk Aedes aegypti)

Tabel 3. Analisis Perbedaan Ikan Cupang (Betta sp.) dan Ikan Guppy (Poecilia reticulata) sebagai predator Larva Instar III Nyamuk Aedes aegypti Tahun 2015

\begin{tabular}{lccc}
\hline $\begin{array}{l}\text { Daya Makan } \\
\text { Ikan }\end{array}$ & $\begin{array}{c}\text { Rata- } \\
\text { Rata }\end{array}$ & $\mathbf{t}$ & $\begin{array}{c}\mathbf{p} \\
\text { value }\end{array}$ \\
\hline Ikan Guppy & 29,90 & - & 0,000 \\
Ikan Cupang & 58,30 & 5,493 & 0 \\
\hline
\end{tabular}

Berdasarkan Tabel 3 diketahui pada perlakuan ikan guppy mendapatkan nilai mean 29,90 sedangkan ikan cupang mendapatkan nilai mean 58,30. Hasil uji statistik dengan uji Independent Samples Test didapatkan nilai $p$ value 0,000 . Hasil ini memberikan kesimpulan adanya perbedaan yang bermakna antara daya makan ikan cupang (Betta sp.) dan ikan guppy (Poecilia reticulata) sebagai predator larva instar III nyamuk Aedes aegypti dengan tingkat predasi yang paling efektif adalah ikan cupang (Betta splendens). 


\section{PEMBAHASAN}

\section{Daya Predator Ikan Guppy (Poecilia reticulata)}

Hasil penelitian mendapatkan bahwa daya predasi ikan guppy pada 1 jam pertama paling banyak adalah 20 ekor, pada 2 jam paling banyak 25 ekor, pada 4 jam sebanyak 39 ekor dan pada 6 jam 47 ekor. Hal ini menunjukkan bahwa tingkat predasi ikan guppy cukup tinggi terhadap larva instar III. Ikan guppy mempunyai tingkat ketangkasan sebagai predator yang baik terhadap larva nyamuk, yang mana kebiasaan makan ikan guppy adalah pada siang hari.

Pemberantasan jentik nyamuk Aedes aegypti secara biologi dapat dilakukan dengan memelihara ikan pemakan jentik nyamuk seperti ikan guppy lokal (Gandahusada, 2008). Ikan guppy yang diperlihara di sekitar hunian dapat mengurangi angka bebas jentik. Hal ini dibuktikan dari penelitian Nugroho (2009) yang mem-buktikan bahwa dengan adanya ikan pemakan larva Aedes aegypti ini maka terjadi pemangsaan terhadap larva Aedes aegypti oleh predator larva sehingga mengakibatkan tidak adanya larva yang ditemukan pada kontainer yang sama dengan ditemukannya predator larva Aedes aegypti.

\section{Daya Predator Ikan Cupang (Betta sp.)}

Hasil penelitian mendapatkan bahwa daya predasi ikan cupang pada 1 jam pertama paling banyak adalah 39 ekor, pada 2 jam paling banyak 54 ekor, pada 4 jam sebanyak 72 ekor dan pada 6 jam 89 ekor. Hal ini menunjukkan bahwa ikan cupang mempunyai daya makan yang baik dalam mengendalikan larva instar nyamuk Aedes aegypti. Ikan cupang mempunyai daya tarik tersendiri bagi masyarakat sebagai ikan hias sehingga hal ini efektif untuk menurunkan angka bebas jentik. Penelitian Tarihoran (2009) membuktikan bahwa rata-rata daya makan ikan cupang mencapai 56 ekor. Hal ini menunjukkan bahwa ikan cupang mempunyai daya makan yang baik terhadap larva instar III.

Penelitian Yogyana (2013) kondisi lingkungan dapat mempengaruhi keberadaan larva. Pemeliharaan ikan predator seperti ikan cupang dapat menurunkan jumlah jentik. Karakteristik ikan cupang dalam memangsa larva adalah ikan cupang langsung memakan jentik, tidak mengubah rasa air. Cara tersebut merupakan salah satu alternatif pencegahan terhadap penyakit demam berdarah. Penelitian Taviv (2011) Hasil intervensi dengan pemanfaatan Ikan Cupang (Betta sp.) plus pemantau jentik lebih efektif meningkatkan Angka Bebas Jentik (ABJ) dibandingkan hanya dengan pemantau jentik. Namun predator larva Aedes aegypti di lapangan masih jarang ditemukan padahal predator larva Aedes aegypti ini selain dapat menekan perkembangan larva juga dapat dipelihara sebagai ikan hias misalnya ikan cupang. Hal ini mungkin terjadi karena sebagian besar masyarakat enggan untuk memelihara ikan karena sibuk dengan aktivitas mereka seharihari sehingga merasa tidak punya waktu untuk mengurusi ikan peliharaan dan membersihkan aquarium maupun toples yang biasa digunakan untuk menampung ikan peliharaan.

\section{Perbedaan Daya Predator Ikan Cupang (Betta sp.) dan Ikan Guppy (Poecilia reticulata) terhadap Larva Instar III Nyamuk Aedes aegypti}

Hasil penelitian mendapatkan kesimpulan adanya perbedaan yang bermakna antara ikan cupang (Betta sp.) dan ikan guppy (Poecilia reticulata) sebagai predator larva instar III nyamuk Aedes aegypti. Penelitian mendapatkan bahwa ikan cupang lebih efektif sebagai pengendali larva nyamuk dibandingkan ikan guppy. Ikan guppy mendapatkan nilai mean 29,90 ekor, sedangkan ikan cupang mendapatkan nilai mean 58,30 ekor dengan selisihnya 28.4 ekor. Hal ini menunjukkan bahwa ikan cupang lebih banyak dalam memangsa yang dikarenakan ikan cupang mempunyai ketangkasan dan kecepatan dalam memangsa larva.

Perkembangbiakan larva dimulai dari stadium telur sampai menjadi nyamuk dewasa. Telur nyamuk Aedes aegypti dipengaruhi kondisi fisik lingkungan. Suhu sangat mempengaruhi perkembangan parasit 
dalam tubuh nyamuk, makin tinggi suhu (sampai batas tertentu) makin pendek masa inkubasi ekstrinsik (sporogoni) dan sebaliknya makin rendah suhu makin panjang masa inkubasi ekstrinsiknya (Gandahusada, 2008). Syarat untuk berkembang biak larva Aedes aegypti yaitu berada pada kelembaban yang kondusif adalah antara 60\%-80\%, sedangkan tingkat kelembaban $60 \%$ merupakan batas yang paling rendah untuk memungkinkan hidupnya nyamuk. Kelembaban udara dapat mempengaruhi longevity (umur) nyamuk. Sistem pernafasan nyamuk menggunakan pipa udara yang disebut trachea dengan lubang dinding yang disebut spiracle. Pada waktu kelembaban rendah, spiracle terbuka lebar tanpa ada mekanisme pengaturnya sehingga menyebabkan penguapan air dari dalam tubuh nyamuk. Kondisi tersebut dan beberapa faktor seperti keasaman air, PH, limbah, dapat mempengaruhi keberadaan larva nyamuk Aedes aegypti (Depkes, 2010).

Nyamuk merupakan vektor pembawa penyakit bagi manusia, contohnya nyamuk Aedes aegypti yang menyebarkan penyakit Demam Berdarah Dengue. Guna mencegah penularan tersebut dan memutuskan rantai perkembangbiakan nyamuk serta kemungkinan dampak negatif yang ditimbulkan oleh nyamuk Aedes aegypti, perlu pengendalian terhadap populasi nyamuk. Pengendalian dapat dilakukan secara fisika, biologi, maupun kimia, namun cara kimia ini dapat menimbulkan efek negatif berupa pencemaran lingkungan dan sulit terurai di alam (PPM, 2010).

Langkah preventif tidak hanya cukup mempengaruhi secara fisik, namun secara biologi juga perlu dilakukan dengan memanfaatkan mahluk hidup seperti ikan predator. Dalam penelitian ini menggunakan perlakukan ikan gupi dan ikan cupang. Sebagai ikan predator, ikan harus mempunyai persyaratan khsusus yaitu harus lebih besar dari mangsanya. Larva instar III mempunyai gerakan yang cepat dan lincah sehingga hal ini dapat menjadi kendala bagi pradator untuk memangsa larva tersebut. Hal ini yang menjadikan perbedaan daya makan antara ikan cupang dan gupi yang mana ikan cupang lebih gesit untuk mengusai mangsanya sehingga daya makannya lebih tinggi.

Penelitian Taviv (2009) membuktikan bahwa keadaan ikan cupang untuk menyerang mangsanya lebih besar dengan batas kemampuannya dalam waktu tertentu. Selain itu faktor ikan sendiri yang meliputi tingkat kemahiran (ketangkasan) dan ukuran tubuh akan mempengaruhi daya makan terhadap larva instar. Tingkat perkembangan larva juga menentukan kecepatan ikan untuk memangsanya. Damaiyanti (2006) membuktikan bahwa ukuran pemangsa dan yang dimangsa mempunyai korelasi positif. Perbedaaan ikan guppy dan ikan cupang terletak pada kemahiran dalam memangsa larva. Penelitian Tarihoran (2009) membuktikan bahwa ikan cupang hias lebih efektif sebagai predator larva instar III, hal ini disebabkan tingkat ketangkasan ikan cupang hias lebih baik dalam memangsa.

\section{KESIMPULAN}

1. Daya predator ikan cupang terhadap larva instar III adalah dengan rata-rata 58.30 ekor dengan daya makan paling rendah adalah 32 ekor dan daya makan paling banyak adalah 89 ekor dalam waktu 6 jam.

2. Daya predator ikan guppy terhadap larva instar III adalah dengan rata-rata 29.9 ekor dengan daya makan paling rendah adalah 12 ekor dan daya makan paling banyak adalah 47 ekor dalam waktu 6 jam.

3. Ada perbedaan antara daya predator ikan cupang (Betta sp.) dan ikan guppy (Poecilia reticulata) terhadap larva instar III nyamuk Aedes aegypti ( $p$ value 0.000 ).

4. Ikan cupang lebih efektif sebagai predator larva instar III nyamuk Aedes aegypti dibandingkan ikan guppy.

\section{SARAN}

1. Bagi Peneliti Selanjutnya

Peneliti selanjutnya dapat mengaplikasikan penggunaan ikan predator di tempat perindukan alami nyamuk Aedes 
aegypti untuk mengetahui efektivitas penurunan Angka Bebas Jentik.

2. Bagi Masyarakat Lebih memperhatikan kegiatan PSN secara mandiri dan lebih teratur serta memanfaatkan ikan sebagai pemangsa larva nyamuk.

3. Bagi Puskesmas

Diharapkan petugas dapat menggerakkan masyarakat melalui edukasi untuk menggunakan ikan sebagai PSN alami.

\section{DAFTAR PUSTAKA}

Damaiyanti, E. 2006. Respon Fungsional Ikan Sepat Biru (Trichogaster Trichopterus) Terhadap Lava Aedes Aegypti Di Laboratorium. http://indonesia.digitaljournals.org/in dex.php/BPKESE/article/download/97 1102

Depkes RI. 2010. Perilaku Hidup Nyamuk Aedes aegypti Sangat Penting Diketahui Dalam Melakukan Kegiatan Pemberantasan Sarang Nyamuk Termasuk Pemantauan Jentik Berkala. Dirjen PPM. Jakarta.

Depkes RI. 2011. Modul Pengendalian Demam Berdarah Dengue. Diakses $21 \quad$ Pebruari 2015. http://pppl.depkes.go.id/.pdf.

Depkes RI. 2015. Demam Berdarah Biasanya Mulai Meningkat di Januari. Diakses 21 Pebruari 2015. http://www.litbang.kemkes.go.id/node 1629.

Gandahusada, S. 2008. Parasitologi Kedokteran. EGC. Jakarta

Notoatmodjo, S. 2010. Metodologi Penelitian Kesehatan. Ed. 3. PT. Rineka Cipta. Jakarta.

Nugroho, F.S. 2009. Faktor-Faktor Yang Berhubungan Dengan Keberadaan Jentik Aedes aegypti di RW IV Desa Ketitang Kecamatan Nogosari
Kabupaten

Boyolali.

http://eprints.ums.ac.id.

Perkasa, B. E. 2010. Merawat Cupang Hias untuk Kontes. Penerba Swadaya. Jakarta.

Riwidikdo, H. 2007. Statistik Kesehatan. EGC, Jakarta.

Samsudrajat, A. 2008. Pengendalian Vektor Di Laboratorium B2P2VRP Salatiga. Diakses $21 \quad$ Pebruari 2015. https://agus34drajat.files.com.

Sari, T.Y. 2005. Perbedaan Kemampuan Ikan Guppy Lokal Poecilia reticulate Memakan Larva Nyamuk Aedes aegypti Berdasarkan Ukuran Panjang Tubuh Dan Jenis Kelamin. Jurnal Kesehatan Masyarakat Undip. Diakses $\quad 30 \quad$ April 2015. http://eprints.undip.ac.id/4057/1/2333. pdf.

Sastroasmoro \& Ismael. 2011. Dasar Metodologi Penelitian Klinis. Sagung Seto: Jakarta.

Tarihoran, H.W. 2009. Perbedaan Ikan Cupang Bias (Betta Splendens Crown Tail) Dan Ikan Hias Maanvis (Pterophyllum Altum) Sebagai Predator Jentik Nyamuk. Diakses 12 Juli 2015.

Taviv, Y. 2007. Efektivitas Ikan Cupang (Ctenops vittatus) dalam Pengendalian Larva dan Daya Tahannya terhadap Temephos (Uji Laboratorium dan Lapangan). Jurnal Ekologi Kesehatan Badan Litbang Depkes RI Vol: 6, No.2 Litbangkes Jakarta. Diakses 21 Pebruari 2015.

Taviv, Y. 2011. Pengendalian DBD Melalui Pemanfaatan Pemantau Jentik Dan Ikan Cupang Di Kota Palembang. Health Science Journals: Indonesia. Diakses tanggal 2 Mei 2015. 
Utama, C. 2010. Tingkat Predasi Ikan Mujair (Oreochromis mossaambicus) Terhadap Larva Nyamuk Aedes aegypti. Diakses 21 Pebruari 2015.
Yogyana, L. 2013. Hubungan karakteristik lingkungan kimia dan biologi dengan keberadaan larva aedes aegypti di wilayah endemis DBD di Kelurahan Kassi-Kassi Kecamatan Rappocini Kota Makassar tahun 2013. 